\title{
Liberalizing Trade between Large and Small: The Welfare from Three Different Strategies
}

\author{
Carsten Kowalczyk ${ }^{* * \dagger}$ \\ a The Fletcher School, Tufts University
}

\begin{abstract}
Much trade liberalization involves large and small countries. This paper presents a formal comparison of the economic welfare effects for the small and large country from unilateral free trade by the small country, from a free trade agreement, and from preferential access to the large country's market. I show that it matters for the welfare effects of these strategies whether the small country has an effect on the domestic price in its partner's domestic market or not. For example, if the small country is so small that it does not, then, paradoxically, a reduction of the small country's tariff reduces the large partner's welfare.
\end{abstract}

JEL Classification: F00, F02, F10, F11, F13, F14, F15

Keywords: small and large countries, free trade areas, unilateral liberalization, preferential market access

\section{Introduction}

What does a small country gain from integrating with a large one? And what are the welfare effects for a large country from integrating with a small one? This paper considers these questions.

It is an important question for developing countries which trade liberalization strategy to pursue with respect to high-income trading partners. Aside from participating in multilateral negotiations and liberalization, which I do not discuss in this paper, options include unilateral liberalization, engaging in free trade agreements with high-income countries, or utilizing preferential access for their exports to the high-income partner markets without reducing own tariffs. Assuming a developing country is a small country, I derive the welfare effects from each of these options for both the small and for the large country that would be a partner in any free trade agreement or preferential arrangement.

* The Fletcher School, Tufts University, MA 02155, USA; Telephone: 617627 5603; Telefax: 617.627.3712; Email: carsten.kowalczyk@tufts.edu.

${ }^{\dagger}$ Financial support from the City University of Hong Kong is gratefully acknowledged. 
It was received wisdom that a small country, defined as a country unable to affect unilaterally its own terms of trade, would obtain maximum real income from unilateral free trade. However, Wonnacott and Wonnacott (1981) demonstrated that a small country can do better by signing a free trade agreement with a large country. I showed (Kowalczyk, 2000) that the small country, under certain conditions, would even wish to sign free trade agreements with multiple large countries. These papers demonstrate also that the large country would lose real income from such integration. In a first analysis that recognizes that not all small countries are of the same size, Michaely (1998) shows that the welfare of a large country from engaging in a free trade agreement with a small one is U-shaped in the size of the small trading partner: there is virtually no loss from integrating with a micro-state or with a country that is almost the same size as the large country, but there is a loss from integrating with an intermediate size small country. ${ }^{1}$

I extend the analysis of liberalization between countries of different size to consider not only the effects on the large country from a free trade agreement but also to consider the effects from unilateral liberalization by the small country, and from preferential access to the large partner's market. I compare these to the welfare from the free trade agreement for both the large and the small country. While Michaely's (op. cit.) analysis is diagrammatic and qualitative, and discusses the findings by use of Jacob Viner's (1950) trade diversion and trade creation approach, I apply the welfare economics of tariff reform to the issues.

Section 2 presents the welfare expression and the model of world trade. Section 3 derives the welfare of the small country and section 4 the welfare of the large country from the three liberalization strategies under consideration. Section 5 concludes.

\section{The Economic Welfare Calculus}

Consider a world of three countries $a, b$, and $c$, indexed by $i(i=a, b, c)$. In each country $i$, goods indexed by $g(g=0,1, \ldots G)$, are demanded by price taking consumers and produced by price taking firms. Define $m_{g}^{i j}$ to be country $i$ 's net imports (exports are negative entries) from country $j$ of $\operatorname{good} g(i, j \stackrel{g}{=} a, b, c ; i \neq j)$, and let $m^{i j}$ be the corresponding vector.

The domestic, tariff-inclusive, price for good $g$ in country $i$ is given by $p_{g}^{i}$, and $\left(p_{g}^{e}\right)^{i j}$ is the tariff-exclusive price paid by consumers in $i$ for imports of good $g$ from country $j$. Assuming that tariffs are quoted as specific rates, and that $t_{g}^{i j}$ is the tariff in country $i$ on imports of good $g$ from country $j, p_{g}^{i}=\left(p_{g}^{e}\right)^{i j}+t_{g}^{i j}$ or, in vector notation, $p^{i}=\left(p^{e}\right)^{i j}+t^{i j}$.

Let subscript $A$ denote a pre-change value and subscript $B$ a post-change value of a variable. Then, if $\Delta$ denotes a change, $\Delta\left(p^{e}\right)^{i}=\left(p_{B}^{e}\right)^{i}-\left(p_{A}^{e}\right)^{i}$ and $\Delta m^{i}=m_{B}^{i}-m_{A}^{i}$ are the changes in country $i$ 's tariff-exclusive prices and trade volume respectively.

Let $e^{i}\left(p^{i}, u^{i}\right)$ be the minimum expenditure required to reach representative consumer utility $u^{i}$ at domestic price $p^{i}$. If $c_{A}^{i}$ is the initial expenditure-minimizing consumption bundle in country $i$, and $y^{i}$ is the vector of profit-maximizing output in country $i$,

\footnotetext{
${ }^{1}$ Kowalczyk (2006) presents a formal analysis of the U-shaped welfare locus, and addresses some questions regarding the large country's welfare posed by Michaely.
} 
$S_{\gamma}^{i}=p_{B}^{i} c_{A}^{i}-e^{i}\left(p_{B}^{i}, u_{A}^{i}\right)$ is the consumption effect in country $i$ due to the reduction in consumer spending required to reach the initial level of utility from a change in domestic price, and $S_{\pi}^{i}=p_{B}^{i}\left(y_{B}^{i}-y_{A}^{i}\right)$ is the production effect from the increase in production value as producers adjust their plans to a change in domestic price. Assuming convex preferences and production possibilities, $S_{\gamma}^{i}$ and $S_{\pi}^{i}$ are non-negative, as is $S^{i}=S_{\gamma}^{i}+S_{\pi}^{i}$.

Let good 0 be the numeraire good, and choose $p_{0}^{e} \equiv 1$. Define $\Delta \eta^{i}$ to be the change in country $i$ 's economic welfare as measured in units of good 0 . Then, as discussed by James Meade (1955), and as formalized by Ronald Jones (1969) for small changes, and by Michihiro Ohyama (1972) and Earl Grinols and Kar-yiu Wong (1991) for large changes, the change in country $i$ 's welfare can be written as:

$$
\Delta \eta^{i}=-\Delta\left(p^{e}\right)^{i} m_{A}^{i}+\left(p_{B}^{i}-\left(p_{B}^{e}\right)^{i} \Delta m^{i}+S^{i} ; i=a, b, c\right.
$$

This states the change in welfare as the sum of a terms-of-trade effect measuring the difference in the cost of obtaining the pre-change net trade vector, a volume-of-trade (or tariff revenue) effect measuring the contribution from a change in tariff revenue evaluated at post-change rates and prices, and the sum of non-negative consumption and production effects $S^{i} .^{2}$

Consider a world economy where each of the three countries applies non-discriminatory import tariffs in the initial situation $A$. I assume country $a$ is large relative to country $b$ but small relative to country $c$ (the "rest of the world"). Suppose there are only two goods, 0 and 1 , and that in the initial situation country $a$ imports good 1 from both countries $b$ and $c$ in return for good 0 , and that countries $b$ and $c$ do not trade with each other.

The standard definition of a small country is that no unilateral action by such a country can affect the international prices at which it trades. If large country $a$ integrates with a small country $b$ like this, the domestic price in country $a$ would not change. ${ }^{3}$ Measuring small country $b$ 's size by the volume of country $a$ imports from $b$, the largest size of small country $b$ consistent with no effect on country $a$ 's domestic price is where large country $a$ obtains all its imports from small country $b$, but where the marginal unit of imports could be from the rest of the world $c$. Michaely (op. cit.) refers to this range of country $b$ sizes as "ultra" small. In a departure from conventional work on small countries, Michaely considers also when the size of a small country is large enough to affect the domestic prices in large country $a$. I will refer to a country $b$ falling in this unconventional size range as "price-affecting" small.

\section{Comparing Welfare for the Small Country}

I will now consider the economic welfare for the small country $b$ from a unilateral elimination of its trade barriers, from joining large country $a$ in a free trade agreement, or from receiving preferential access for its exports to country $a$ 's domestic market without

\footnotetext{
${ }^{2}$ See Ohyama (1972) or Grinols and Wong (1991) for a derivation of expression (1).

${ }^{3}$ This would happen, for example, if country $b$ were a microstate, in which case country $a$ continues to obtain virtually all its imports from country $c$.
} 
reducing own import barriers.

The change in small country $b$ 's welfare from any change in policy - own or that of other countries, or a combination of own and others' policies - follows from expression (1) as:

$$
\Delta \eta^{b}=-\Delta\left(p^{e}\right)^{b} m_{A}^{b a}+\left(p_{B}^{b a}-\left(p_{B}^{e} b a\right) \Delta m^{b a}-\Delta\left(p^{e}\right)^{b} m_{A}^{b c}+\left(p_{B}^{b c}-\left(p_{B}^{e}\right)^{b c}\right) \Delta m^{b c}+S^{b}\right.
$$

If small country $b$ eliminates its tariff unilaterally (UFT), its welfare changes by:

$$
\Delta \eta^{b}(U F T)=S_{U F T}^{b}
$$

Let $X_{A}^{b a}$ be country $b$ 's initial exports to country $a$. If small country $b$ enters a free trade agreement (FTA) with large country $a$, and if country $b$ is "ultra" small, then country $b$ 's export price increases by $\Delta\left(p^{e}\right)_{\text {Exports }}^{b}=t_{A}^{a}$. The country experiences a terms of trade improvement equal to $t_{A}^{a} X_{A}^{b a}$, as well as production and consumption effects, $S_{F T A}^{b}$, due to the lower domestic price of imports and the higher export price. The change in country $b$ 's welfare is:

$$
\Delta \eta^{b}(F T A)=t_{A}^{a} X_{A}^{b a}+S_{F T A}^{b}
$$

If large country $a$ grants preferential access (PA), i.e., if country $a$ eliminates its tariff on imports from "ultra" small country $b$ without any reduction in country $b$ 's tariff, country $b$ 's export revenue would increase as from the free trade agreement. Its tariff revenue would also increase, and there would be production and consumption effects:

$$
\Delta \eta^{b}(P A)=t_{A}^{a} X_{A}^{b a}+t_{A}^{b}\left(m_{B}^{b a}-m_{A}^{b a}\right)+S_{P A}^{b}
$$

Compare now the welfare effects from unilateral free trade and a free trade agreement. The free trade agreement implies improved terms of trade, $t_{A}^{a} X_{A}^{b a}$. Also, while the change in the "ultra" small country's domestic price of imports is the same in the two cases, the domestic price of the exported good is higher with the free trade agreement, hence the change in relative price, and thus the production and consumption effects, will be larger with the free trade agreement. So, the free trade agreement welfare dominates unilateral free trade for the "ultra" small country.

Preferential market access yields a terms of trade improvement in addition to production and consumption effects, while unilateral liberalization yields only production and consumption effects. For a high initial small country tariff, unilateral free trade could yield higher welfare than preferential access. Of course, if large country $a$ 's initial tariff is high compared to small country $b$ 's, the ranking could be reverse.

Compare, finally, a free trade agreement to preferential market access. The terms of trade effects from the improved access for the small country's exports are the same in expressions (4) and (5), and hence the welfare ranking depends on comparing $S_{F T A}^{b}$ to $t_{A}^{b}\left(m_{B}^{b a}-m_{A}^{b a}\right)+S_{P A}^{b}$. For the given increase in export price, and for any positive degree of substitutability, this amounts to the difference in welfare for a small country between the welfare from unilateral tariff elimination, $S_{F T A}^{b}$, and a partial unilateral tariff reduction. Since, for a small country, no tariff is better than any tariff, $S_{F T A}^{b}>t_{A}^{b}\left(m_{B}^{b a}-m_{A}^{b a}\right)+S_{P A}^{b}$. 
Proposition 1 For an ultra-small country, a free trade agreement with a large partner yields higher welfare than unilateral free trade or preferential market access. The ranking between unilateral free trade and preferential market access is ambiguous.

Suppose instead, small country $b$ is "price-affecting" small, i.e., suppose small country $b$ is so large that it has the potential to become the sole supplier to the large country $a$ market, and thus able to affect the domestic price in large partner $a$.

In this case, a unilateral elimination of country $b$ 's tariff (UFT), implies a terms of trade worsening for country $b$, as well as production and consumption effects. The change in country $b$ 's welfare becomes:

$$
\Delta \eta^{b}(U F T)=\left(\left(p_{B}^{e}\right)^{b a}-\left(p_{A}^{e}\right)^{b a}\right) X_{A}^{b a}+S_{U F T}^{b}
$$

The sign of this expression is ambiguous. If country $b$ 's initial tariff is smaller than or equal to its optimal rate then country $b$ 's welfare falls from eliminating its tariff. If its initial tariff is sufficiently larger than its optimal rate, then country $b$ 's welfare may increase from eliminating its tariff unilaterally.

If "price-affecting" small country $b$ enters a free trade agreement (FTA) with large country $a$, country $b$ experiences a terms of trade improvement, but not by the full amount of country $a$ 's tariff rate since $b$ 's cost increases.

The change in country $b$ 's welfare is:

$$
\Delta \eta^{b}(F T A)=\left(\left(p_{B}^{e}\right)^{b a}-\left(p_{A}^{e}\right)^{b a}\right) X_{A}^{b a}+S_{F T A}^{b}
$$

Finally, if large country $a$ grants preferential access (PA), country $b$ would experience a terms of trade improvement, $\left(\left(p_{B}^{e}\right)^{b a}-\left(p_{A}^{e}\right)^{b a}\right) X_{A}^{b a}$, increased tariff revenue, $t_{A}^{b}\left(m_{B}^{b a}-m_{A}^{b a}\right)$, and production and consumption effects, $S_{P A}^{b}$.

The change in small country $b$ 's welfare would be:

$$
\Delta \eta^{b}(P A)=\left(\left(p_{B}^{e}\right)^{b a}-\left(p_{A}^{e}\right)^{b a}\right) X_{A}^{b a}+t_{A}^{b}\left(m_{B}^{b a}-m_{A}^{b a}\right)+S_{P A}^{b}
$$

Since the free trade agreement implies an unambiguous terms of trade improvement and larger production and consumption effects than unilateral liberalization, the free trade agreement welfare dominates unilateral liberalization for the "price-affecting" small country.

Preferential access implies a terms of trade improvement and increased tariff revenue, while unilateral free trade implies a terms of trade worsening. A high initial small country tariff might make $S_{U F T}^{b}$ large, but a high value of $t_{A}^{b}$ would also tend to imply a large increase in tariff revenue from preferential access. So, as for the "ultra" small country, the ranking is ambiguous.

In contrast to the case of the "ultra-small" country, the terms of trade improvement from improved access is larger than that from the free trade agreement when the country is "price-affecting" small. In addition, preferential access raises tariff revenue. On the other hand, the production and consumption effects from improved access will be smaller than those from the free trade agreement. Thus, the ranking between the two is ambiguous. 
Proposition 2 For a price-affecting small country, a free trade agreement with a large partner yields higher welfare than unilateral free trade. Any ranking involving preferential access is ambiguous.

Suppose country $b$ were to pay compensation to the large country for the latter's terms of trade loss on its initial trade with country $b$ due to either a free trade agreement or preferential access. If country $b$ is "ultra" small, the transfer is:

$$
T^{b a}=t_{A}^{a} X_{A}^{b a}
$$

If country $b$ is "price-affecting" small, the transfer is:

$$
T^{b a}=\left(\left(p_{B}^{e}\right)^{b a}-\left(p_{A}^{e}\right)^{b a}\right) X_{A}^{b a}
$$

Subtracting these from the appropriate expressions for changes in welfare from a free trade agreement and preferential access will make a free trade agreement and preferential access less attractive to the small country. The free trade agreement is still the "ultra" small country's preferred option, since it yields the largest production and consumption effects. But the likelihood that preferential access yields higher welfare than unilateral liberalization is reduced. For the "price-affecting" small country, a free trade agreement continues to be better than unilateral free trade, and any ranking involving preferential access continues to be ambiguous.

\section{The Large Country's Welfare}

To analyze the effects on the large country $a$ from these alternatives, it is helpful to rewrite equation (1) as:

$$
\Delta \eta^{a}=-\left(\left(p_{B}^{e}\right)^{a b}-\left(p_{A}^{e}\right)^{a b}\right) m_{A}^{a b}-\left(\left(p_{B}^{e}\right)^{a b}-\left(p_{A}^{e}\right)^{a c}\right) m_{A}^{a c}-t_{A}^{a} m_{A}^{a c}+S^{a}
$$

Suppose first that country $b$ is "price-affecting" small, and that no compensation is involved. Unilateral free trade by $b$ would improve country $a$ 's terms of trade, raise $a$ 's tariff revenue, and induce production and consumption effects. A free trade agreement would worsen $a$ 's terms of trade, eliminate its tariff revenue, but trigger larger production and consumption effects than $b$ 's unilateral tariff elimination. Finally, granting preferential access would worsen country $a$ 's terms of trade by more than the free trade agreement, eliminate $a$ 's tariff revenue, and create smaller production and substitution effects than would the free trade agreement. So, if the small country is "price-affecting," the large partner prefers a free trade agreement to granting preferential access. If the large country's tariff does not exceed its optimal rate, it would, furthermore, prefer unilateral liberalization by the small partner to a free trade agreement.

Suppose, instead, country $b$ is "ultra" small in which case the domestic price in $a$ does not change. Now, unilateral free trade by country $b$ will have no effect on country $a$. Since, with no change in country $a$ 's tariff on rest of world $c, t_{B}^{a c}=t_{A}^{a c}=t_{A}^{a}$, the change in country $a$ 's welfare from a free trade agreement with $b$ becomes: 


$$
\Delta \eta^{a}=-t_{A}^{a} m_{A}^{a b}-t_{A}^{a}\left(m_{A}^{a c}-m_{B}^{a c}\right)
$$

This expression states that the large country suffers a terms of trade loss on its initial trade with small country $b,-t_{A}^{a} m_{A}^{a b}$, and a tariff revenue loss on imports that were previously obtained from the rest of the world but are now obtained from small $b$, $t_{A}^{a}\left(m_{A}^{a c}-m_{B}^{a c}\right)$. Granting preferential access to small $b$ also reduces large $a$ 's welfare and, likewise, becomes costlier to country $a$ the more country $b$ is able to trade. In contrast to the case of the "price-affecting" small country, it follows that granting preferential access reduces country $a$ 's welfare by less than does a free trade agreement, since the free trade agreement raises small country $b$ 's desired trade with $a$ and hence raises country $a$ 's loss. In other words, and somewhat paradoxical, the "ultra" small country's domestic tariff liberalization in the free trade agreement is harmful to the large partner country.

Would compensation from small $b$ to large $a$ equal to country $a$ 's terms of trade loss on its initial trade with $b$ alter these findings? If country $b$ is "price-taking" small, a free trade agreement with compensation yields larger production and consumption effects than preferential access with compensation while both yield the same loss of tariff revenue on $a$ 's initial trade with the rest of the world $c$. While the welfare effect for the large country from either of these strategies continues to be ambiguous when compensation is involved it is less likely that either yields negative welfare for country $a$. Indeed, it is even possible that either strategy yields increased welfare and, for large enough production and consumption effects from eliminating the large country's own tariff, a larger increase in welfare than from the "price-affecting" small country's unilateral liberalization.

If country $b$ is "ultra" small instead, compensation for country $a$ 's terms of trade loss on its initial trade with $b$ is not sufficient to make the free trade agreement welfare improving for country $a$ if country $a$ 's imports from the rest of the world are also reduced. ${ }^{4}$ Again, unilateral free trade has no effect while preferential access does but less so than the free trade agreement.

Proposition 3 For a large country trading with a price-affecting small country, unilateral free trade by the small partner raises large country welfare and yields higher welfare for the large country than does a free trade agreement which, in turn, is preferred to granting preferential access. If the small country is ultra-small, unilateral free trade by the small country does not affect the large country's welfare. Granting preferential access to an ultra small country reduces the large country's welfare but by less than does a free trade agreement.

\section{Conclusion}

This paper has presented a complete welfare comparison for three types of liberalization of particular concern for developing countries, assumed to be small countries, and

\footnotetext{
${ }^{4}$ Full compensation would require also a transfer for the loss in tariff revenue, $t_{A}^{a}\left(m_{\mathrm{A}}^{a c}-m_{B}^{a c}\right)$, which would be the increase in country $b$ 's income from increased exports at a price exceeding the initial cost of production.
} 
their trading partners, assumed to be large. I have shown that for the small country it matters for the relative welfare ranking of unilateral free trade, a free trade agreement with a large partner, or preferential access to the large partner's market, whether the small country is "ultra" small, i.e., it has no effect on the domestic price in the partner's market, or whether it is "price-affecting" small, in which case its exports to the partner market could affect the partner's domestic price. In particular, the ranking of preferential access relative to each of the other two options is sensitive to this difference.

It matters also for the large country whether the small partner is "ultra" or "priceaffecting" small. If the partner is "price affecting" small, and hence can affect by its own action its terms of trade, its tariff elimination has beneficial terms of trade effects for the large partner. If, on the other hand, the partner is "ultra" small, its tariff elimination raises its desired trade with the large partner, but that trade is welfare reducing for the large partner. Hence, paradoxically, the small country's tariff reduction bestows a negative welfare effect onto the large partner.

The results of this paper are not recommendations for policy. For example, I do not consider the welfare effects from multilateral liberalization in this paper. However, to the extent countries are considering the three strategies analyzed in this paper, the results suggest that it matters for the relative rankings of strategies - and both for the small and for the large partner country - whether the small country has truly no effect on prices anywhere or whether it has some limited effect on price, in particular in the large partner's market. Also, the analysis in this paper shows that preferential access, a strategy that has received considerable attention in the world of trade policy making, may well fail to be the strategy that yields the highest welfare, whether for the small or for the large country.

\section{References}

Grinols, Earl L., and Kar-yiu Wong, 1991, “An Exact Measure of Welfare Change”, Canadian Journal of Economics 24, 61-64.

Jones, Ronald W., 1969, "Tariffs and Trade in General Equilibrium: Comment", American Economic Review 59, 418-424.*

Kowalczyk, Carsten, (ed.), 1999, Economic Integration and International Trade. International Library of Critical Writings in Economics (Cheltenham, UK: Edward Elgar Publishing Ltd).

Kowalczyk, Carsten, 2000, "Welfare and Integration", International Economic Review 41, 483-494.

Kowalczyk, Carsten, 2006, "Free Trade between Large and Small: What's in It for the Large Country? What's in It for the Small?" The Fletcher School, April, mimeo.

Meade, James, 1955, Trade and Welfare, (London: Oxford University Press).

Michaely, Michael, 1998, "Partners to a Preferential Trade Agreement: Implications of Varying Size", Journal of International Economics 46, 73-85.

Ohyama, Michihiro, 1972, "Trade and Welfare in General Equilibrium”, Keio Economic Studies $9,37-73 .^{*}$

Viner, Jacob, 1950, The Customs Union Issue (New York: Carnegie Endowment for International Peace). 
Wonnacott, Paul, and Ronald Wonnacott, 1981, "Is Unilateral Tariff Reduction Preferable to a Customs Union? The Curious Case of the Missing Foreign Tariffs", American Economic Review 71, 704-714.* 